\title{
Delayed sternal closure after neonatal cardiac operations
}

We retrospectively compared the use of primary elective open sternum coupled with delayed sternal closure with the use of primary sternal closure in neonates after cardiac operations. Primary elective open sternum/delayed sternal closure was selectively used in patients who demonstrated hemodynamic or respiratory deterioration, or both, during an intraoperative trial of sternal closure; otherwise primary sternal closure was used. Primary elective open sternum was used in $55(61.8 \%)$ and primary sternal closure in $34(38.2 \%)$ of the 89 patients studied. Eleven $(20 \%)$ patients having primary elective open sternum died compared with $5(14.7 \%)$ patients having primary sternal closure $(p=0.6)$. Six $(10.9 \%)$ of the patients with primary elective open sternum died before delayed sternal closure; the remaining 49 patients comprise the primary elective open sternum/delayed sternal closure group. The durations of mechanical ventilation $(9.7 \pm 0.9$ days [mean plus or minus standard error of the mean], median 7.7 versus $9.9 \pm 3.4$ days, median $4.9 ; p=0.0005)$ and hospital stay $(21.1 \pm 1.4$ days, median 17.7 versus $19.6 \pm 4.1$ days, median $12.9 ; p=0.004$ ) were shorter in the primary sternal closure group. The overall morbidity and duration of inotropic support were not significantly different between the two groups, although seven $(20.6 \%)$ of the patients with primary sternal closure did have to undergo delayed sternal reopening for refractory postoperative low cardiac output. There was one superficial wound infection in the primary elective open sternum/delayed sternal closure group. Primary elective open sternum/delayed sternal closure is an effective treatment for postoperative neonatal mediastinal compression for the following reasons: (1) the morbidity is low; (2) the mortality of the critically ill group of neonates in whom primary elective open sternum/delayed sternal closure was used was similar to that of the less critically ill primary sternal closure group; and (3) $20.6 \%$ of the primary sternal closure group eventually had to undergo delayed sternal reopening to treat refractory postoperative low cardiac output. (J ThoraC CardiovasC SuRg 1994;107:925-33)

Mehdi Hakimi, MD, Henry L. Walters III, MD, William W. Pinsky, MD, Michael J. Gallagher, BS, and Juanita M. Lyons, MS, Detroit, Mich.

$\mathrm{M}$ yocardial, mediastinal, and pulmonary edema can contribute to low cardiac output and respiratory embarrassment in neonates after cardiac operations. ${ }^{1-4}$ Sternal closure can accentuate these adverse effects in the immediate postoperative period and produce serious clinical deterioration. Initial treatment involves the use of inotro-

From the Department of Cardiovascular Surgery and Division of Pediatric Cardiology, Children's Hospital of Michigan, Wayne State University School of Medicine, Detroit.

Received for publication March 24, 1993.

Accepted for publication July 7, 1993.

Address for reprints: Henry L. Walters III, MD, Department of Cardiovascular Surgery, Children's Hospital of Michigan, 3901 Beaubien Blvd., Detroit, MI 48201.

Copyright ${ }^{(} 1994$ by Mosby-Year Book, Inc.

$0022-5223 / 94 \$ 3.00+0 \quad 12 / 1 / 50474$ pic agents, afterload reducing agents, and the appropriate ventilatory adjustments. When these initial interventions fail, prompt delayed sternal reopening can produce dramatic improvement in the patient's clinical condition by relieving the mediastinal compression. This is often done on an emergency basis and under adverse conditions after a significant interval of low cardiac output or respiratory embarrassment, or both. To avoid the possible morbidity and mortality associated with this delay in treatment, we use the technique of primary elective open sternum (PEOS) followed by delayed sternal closure (DSC) in patients who demonstrate hemodynamic or respiratory compromise during an intraoperative trial of sternal closure. In this retrospective review we compare PEOS/DSC with primary sternal closure (PSC) in neonates. 
Table I. Variables analyzed from the medical records of 89 neonates who underwent open cardiac procedures at Children's Hospital of Michigan from October 1986 through August 1992

\begin{tabular}{|c|c|}
\hline Variable & $\begin{array}{c}\text { Units and mode of } \\
\text { presentation of the data }\end{array}$ \\
\hline Sex & Male/female, No. (\%) \\
\hline Age & Days, mean $\pm \mathrm{SEM}$, median \\
\hline Weight & $\begin{array}{l}\text { Kilograms, mean } \pm \text { SEM } \\
\text { median }\end{array}$ \\
\hline Previous closed operations & No. $(\%)$ \\
\hline $\begin{array}{l}\text { Cardiopulmonary bypass } \\
\text { time }\end{array}$ & Minutes, mean \pm SEM \\
\hline Total circulatory arrest time & Minutes, mean \pm SEM \\
\hline Aortic crossclamp time & Minutes, mean \pm SEM \\
\hline $\begin{array}{l}\text { Global myocardial ischemic } \\
\text { time }\end{array}$ & Minutes, mean \pm SEM \\
\hline $\begin{array}{l}\text { Interval between PEOS and } \\
\text { DSC }\end{array}$ & Days, mean \pm SEM \\
\hline Duration of hospitalization & Days, mean $\pm \mathrm{SEM}$, median \\
\hline $\begin{array}{l}\text { Duration of mechanical } \\
\text { ventilation }\end{array}$ & Days, mean \pm SEM, median \\
\hline $\begin{array}{l}\text { Duration of significant } \\
\text { inotropic support }\end{array}$ & Days, mean \pm SEM, median \\
\hline \multicolumn{2}{|l|}{ Cardiac diagnosis } \\
\hline \multicolumn{2}{|l|}{ Year of index operation } \\
\hline \multicolumn{2}{|l|}{$\begin{array}{l}\text { Technique of myocardial } \\
\text { protection }\end{array}$} \\
\hline \multicolumn{2}{|l|}{ Indication for PEOS/DSC } \\
\hline \multicolumn{2}{|l|}{ Technique of DSC } \\
\hline \multicolumn{2}{|l|}{ Postoperative complications } \\
\hline \multicolumn{2}{|l|}{$\begin{array}{l}\text { Cardiac operations after } \\
\text { index operation }\end{array}$} \\
\hline \multicolumn{2}{|l|}{ Intraoperative mortality } \\
\hline \multicolumn{2}{|l|}{ Hospital mortality } \\
\hline Surgeon of record & \\
\hline
\end{tabular}

SEM, Standard error of the mean.

\section{Patients and methods}

Database. Ninety-four neonates (less than 30 days of age) underwent a cardiac operation at Children's Hospital of Michigan between October 1986 and August 1992. Five (5.3\%) patients who died intraoperatively were eliminated from the study. The medical records of the remaining 89 patients form the raw data for this report.

Analyzed variables and definitions of terms. The analyzed variables are listed in Table I. Previous closed operations included those procedures performed without cardiopulmonary bypass before the open repair (Table II). For the purpose of analysis, the cardiac diagnoses of the patient population (Table III) were arbitrarily assigned to six major groups. Global myocardial ischemic time was defined as the time during which the myocardium received no blood flow and was equal to the aortic crossclamp time or the total circulatory arrest time, whichever was greatest.

Conduct of cardiopulmonary bypass and myocardial protection. Cardiopulmonary bypass was instituted at an initial flow of $3 \mathrm{~L} / \mathrm{min} / \mathrm{m}^{2}$, and a left ventricular vent was inserted immediately. The patient was cooled to $18^{\circ} \mathrm{C}$. The procedures
Table II. Closed cardiac operations in the PEOS and $P S C$ groups done previous to the open heart repair

\begin{tabular}{|c|c|c|c|c|}
\hline \multirow[b]{2}{*}{ Closed operations } & \multicolumn{2}{|c|}{$\operatorname{PEOS}(\mathrm{n}=55)$} & \multicolumn{2}{|c|}{$P S C(\mathrm{n}=34)$} \\
\hline & No. & $\%$ of 55 & No. & $\%$ of 34 \\
\hline Repair coarctation & 3 & 5.5 & 0 & 0 \\
\hline $\begin{array}{l}\text { Repair coarctation \& } \\
\text { hypoplastic arch }\end{array}$ & 2 & 3.6 & 0 & 0 \\
\hline $\begin{array}{l}\text { Repair coarctation \& } \\
\text { aortic valvotomy }\end{array}$ & 1 & 1.8 & 0 & 0 \\
\hline $\begin{array}{l}\text { Repair coarctation \& } \\
\text { PA banding }\end{array}$ & 0 & 0 & 1 & 2.9 \\
\hline $\begin{array}{l}\text { Repair interrupted } \\
\text { aortic arch }\end{array}$ & 1 & 1.8 & 2 & 5.9 \\
\hline Brock procedure & 0 & 0 & 1 & 2.9 \\
\hline Institute ECMO & $\underline{0}$ & 0 & $\underline{1}$ & 2.9 \\
\hline Totals* & $\overline{7}$ & $\overline{12.7}$ & $\overline{5}$ & $\overline{14.7}$ \\
\hline
\end{tabular}

$P A$, Pulmonary artery; $E C M O$, extracorporeal membrane oxygenation. ${ }^{*} p$ Value for the difference between the totals: $p=0.99$ (Fisher's exact test).

were done with low flow ( 1 to $1.5 \mathrm{~L} / \mathrm{min} / \mathrm{m}^{2}$ ) or very low flow $\left(0.3 \mathrm{~L} / \mathrm{min} / \mathrm{m}^{2}\right)$ profoundly hypothermic perfusion. Circulatory arrest was used when necessary.

Three major forms of myocardial protection were used during the study period: deep hypothermia, crystalloid cardioplegia, and blood cardioplegia. Deep hypothermia and crystalloid cardioplegia were used early in the series in a small number of patients (Table IV). In 1988 we began using cold $\left(4^{\circ} \mathrm{C}\right.$ ), hyperkalemic, dilute, sanguineous cardioplegia. Cardioplegia was administered at 20-minute intervals when this was technically feasible. Topical iced saline was applied frequently to maintain myocardial hypothermia. During the last 18 months of the study period, we added a terminal, warm $\left(37^{\circ} \mathrm{C}\right)$ dose of hyperkalemic, dilute, sanguineous cardioplegic solution to our myocardial protection regimen. Gradual rewarming of the patient at full flow $\left(3 \mathrm{~L} / \mathrm{min} / \mathrm{m}^{2}\right)$ was initiated at the onset of myocardial reperfusion. During the reperfusion period, the mean arterial pressure was maintained at $50 \mathrm{~mm} \mathrm{Hg}$ or less. Ultrafiltration has been routinely used since 1989. Calcium chloride was administered at the end of the rewarming phase to restore the ionized calcium level to the normal value. Cardiopulmonary bypass was then discontinued.

Indications for PEOS/DSC. All operations were done by one of two surgeons. In most operations both surgeons were present and participated in the intraoperative decision-making process. Sternal closure was attempted at the end of each procedure. Patients who responded to a trial of sternal closure with low cardiac output were treated medically before being relegated to PEOS/DSC. Volume was administered on the basis of left atrial pressure measurements. We typically used moderate ( 5 to $10 \mu \mathrm{g} / \mathrm{kg} / \mathrm{min}$ ) doses of dopamine* and dobutamine ${ }^{\dagger}$ with or without nitroprussideł for inotropic support and afterload reduction. Hyperventilation, narcotics, paralyzing agents, nitroglycerin,§ prostaglandin $E_{1}, \|$ and tolazoline $\mathbb{I}$ were used as

*Inotropin, DuPont Pharmaceuticals, Manati, Puerto Rico.

†Dobutrex solution, Eli Lilly Industries, Inc., Carolina, Puerto Rico.

‡Sodium nitroprusside, USP, Elkins-Sinn, Inc., Cherry Hill, N.J.

§Tridil, DuPont Pharmaceuticals.

|Prostin VR Pediatric, The Upjohn Co., Kalamazoo, Mich.

IPriscoline, CIBA Pharmaceutical Co., Summit, N.J. 
Table III. Distributions of cardiac diagnoses in the PEOS and PSC groups

\begin{tabular}{|c|c|c|c|c|}
\hline \multirow[b]{2}{*}{ Cardiac diagnosis } & \multicolumn{2}{|c|}{$P E O S(\mathrm{n}=55)$} & \multicolumn{2}{|c|}{$P S C(\mathrm{n}=34)$} \\
\hline & No. & $\%$ of 55 & No. & $\%$ of 34 \\
\hline $\begin{array}{l}\text { Anomalous pulmonary } \\
\text { venous connection }\end{array}$ & 5 & 9.1 & 2 & 5.9 \\
\hline TAPVC & 3 & & 2 & \\
\hline TAPVC \& VSD & 1 & & 0 & \\
\hline $\begin{array}{l}\text { TAPVC \& VSD \& } \\
\text { coarctation }\end{array}$ & 1 & & 0 & \\
\hline $\begin{array}{l}\text { Hypoplastic left heart } \\
\text { syndrome }\end{array}$ & 17 & 30.9 & 6 & 17.6 \\
\hline $\begin{array}{l}\text { Transposition of the } \\
\text { great arteries with } \\
\text { intact septum }\end{array}$ & 18 & 32.7 & 14 & 41.2 \\
\hline TGA & 17 & & 14 & \\
\hline TGA \& coarctation & 1 & & 0 & \\
\hline $\begin{array}{l}\text { Transposition of the } \\
\text { great arteries with } \\
\text { VSD }\end{array}$ & 13 & 23.6 & 1 & 2.9 \\
\hline TGA \& VSD & 10 & & 1 & \\
\hline $\begin{array}{l}\text { TGA \& VSD \& } \\
\text { coarctation }\end{array}$ & 2 & & 0 & \\
\hline $\begin{array}{l}\text { TGA \& VSD \& } \\
\text { IAA }\end{array}$ & 1 & & 0 & \\
\hline VSDs & 1 & 1.8 & 2 & 5.9 \\
\hline VSD \& coarctation & 0 & & 1 & \\
\hline VSD \& IAA & 0 & & 1 & \\
\hline VSD \& RVOTO & 1 & & 0 & \\
\hline Miscellaneous & 1 & 1.8 & 9 & 26.5 \\
\hline Aortic stenosis & 0 & & 1 & \\
\hline $\begin{array}{l}\text { Aortic stenosis \& } \\
\text { coarctation }\end{array}$ & 0 & & 1 & \\
\hline $\begin{array}{l}\text { Aortopulmonary } \\
\text { window \& IAA }\end{array}$ & 0 & & 2 & \\
\hline $\begin{array}{l}\text { Critical pulmonary } \\
\text { stenosis \& intact } \\
\text { septum }\end{array}$ & 0 & & 1 & \\
\hline $\begin{array}{l}\text { Right pulmonary } \\
\text { artery from } \\
\text { ascending aorta }\end{array}$ & 0 & & 1 & \\
\hline Truncus arteriosus & 0 & & 2 & \\
\hline Univentricular heart & 1 & & 1 & \\
\hline
\end{tabular}

$p$ Value for the difference between distributions: $p=0.001$ ( $\chi^{2}$ test). TAPVC, Total anomalous pulmonary venous connection; $V S D$, ventricular septal defect: $T G A$, transposition of the great arteries; $I A A$, interrupted aortic arch; $R V O T O$, right ventricular outflow tract obstruction.

indicated to treat pulmonary artery hypertension. Concurrent respiratory deterioration was treated with the appropriate ventilatory adjustments. The surgeon determined the clinical importance of the hemodynamic and respiratory response; no strict, numeric criteria for the use of PEOS/DSC were used during the study period.

Technique of PEOS/DSC. In all patients the pleural spaces were opened widely, and the inferior aspect of the left pericardium was incised along the diaphragm to within $2 \mathrm{~cm}$ of the left phrenic nerve. This was done to allow maximum expansion of both lungs and to widen the left border of the mediastinum. Two (3.6\%) patients underwent closure of the skin, leaving an open,
Table IV. Technique of myocardial protection

\begin{tabular}{|c|c|c|c|c|c|}
\hline \multirow{2}{*}{$\begin{array}{c}\text { Technique } \\
\text { of } \\
\text { protection }\end{array}$} & \multicolumn{2}{|c|}{$\begin{array}{c}P E O S \\
(\mathrm{n}=55)\end{array}$} & \multicolumn{2}{|c|}{$\begin{array}{c}P S C \\
(\mathrm{n}=34)\end{array}$} & \multirow{2}{*}{$\begin{array}{c}\mathrm{p} \text { Value } \\
\text { for the } \\
\text { difference* }^{*}\end{array}$} \\
\hline & No. & $\begin{array}{c}\% \text { of } \\
55\end{array}$ & No. & $\begin{array}{c}\% \text { of } \\
34\end{array}$ & \\
\hline $\begin{array}{l}\text { Blood } \\
\text { cardioplegia }\end{array}$ & 49 & 89.1 & 29 & 85.3 & 0.7 \\
\hline $\begin{array}{l}\text { Crystalloid } \\
\text { cardioplegia }\end{array}$ & 1 & 1.8 & 3 & 8.8 & 0.3 \\
\hline $\begin{array}{l}\text { Deep } \\
\text { hypothermia }\end{array}$ & 5 & 9.1 & 2 & 5.9 & 0.7 \\
\hline
\end{tabular}

unstented sternum beneath; the technique of PEOS/DSC was uniform in the remaining $53(96.4 \%)$ patients.

After placement of the intracardiac pressure monitoring lines and epicardial pacing wires, two mediastinal tubes were placed. A bovine pericardial* (7 patients, $12.7 \%$ ) or Gore-Tex $\uparrow(46$ patients, $83.6 \%$ ) patch was sutured to the skin edge with a running 5-0 Prolene suture, $\neq$ and the unstented sternal edges beneath were left open. To avoid strangulation of the skin edge, the Prolene suture was widely spaced and firm, but not tight (Fig. 1). Povidone-iodine ointment $\S$ was applied liberally to the completed suture line. Gauze sponges were placed over the entire wound and covered with an iodine-impregnated sterile drape. The patient was transported to the pediatric intensive care unit where he or she was sedated with a continuous, intravenous narcotic infusion and received full ventilation. Muscle relaxants were used selectively when paralysis was desirable. The mediastinal tubes were adjusted to -10 to $-20 \mathrm{~cm} \mathrm{H}_{2} \mathrm{O}$ suction until mediastinal drainage was minimal. They were then converted to gravity drainage to minimize the volume of ambient air drawn into the mediastinum through air leaks that were invariably present along the patch suture line. Unless postoperative bleeding necessitated surgical reexploration, the occlusive dressing was not disturbed before DSC.

During the interval between PEOS and DSC, the patient's hemodynamic status was optimized with volume expansion, inotropic agents, and vasodilators. Typically the inotropic agents and vasodilators were withdrawn within 48 to 72 hours as the patient's hemodynamic status stabilized. By the time of DSC all patients were being maintained empirically on no more than 6 $\mu \mathrm{g} / \mathrm{kg} / \mathrm{min}$ of dopamine to optimize renal perfusion. During the initial 24 to 48 postoperative hours, the patients uniformly maintained a positive fluid balance and some degree of anasarca developed. After initial hemodynamic stabilization, diuresis was stimulated with intravenous diuretics. When the patient's hemodynamic state was stable and after the anasarca had largely resolved, DSC was attempted.

*PeriGuard processed bovine pericardium, Bio-Vascular, Inc., St. Paul, Minn.

†Gore-Tex patch (soft tissue), registered trademark of W. L. Gore \& Associates, Inc., Newark, Del.

‡Ethicon, Inc., Somerville, N.J.

§Betadine ointment (povidone-iodine, 10\%), The Purdue Frederick Co., Norwalk, Conn.

IIoban 2 (Iodophor), 6650 antimicrobial film, Medical-Surgical Division/3M, St. Paul, Minn. 


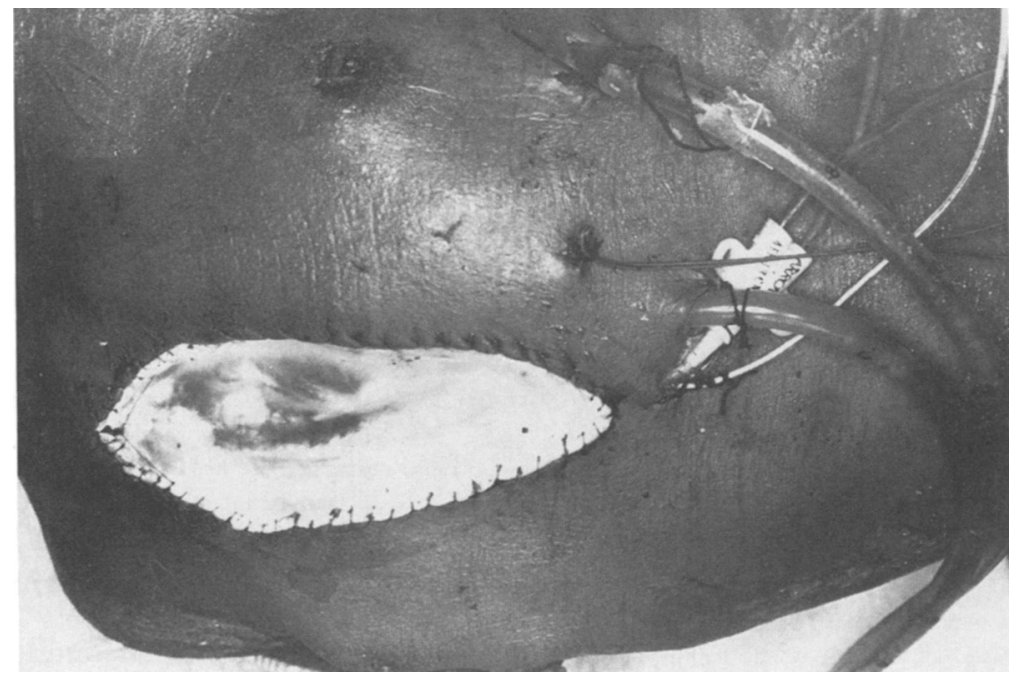

Fig. 1. Operative photograph of polytetrafluoroethylene patch immediately before DSC.

Table V. Preoperative characteristics of the PEOS and PSC groups

\begin{tabular}{|c|c|c|c|}
\hline Patient characteristic & $\begin{array}{c}P E O S \\
(\mathrm{n}=55)\end{array}$ & $\begin{array}{c}P S C \\
(\mathrm{n}=34) \\
\end{array}$ & $\begin{array}{l}\mathrm{p} \text { Value } \\
\text { for the } \\
\text { difference }\end{array}$ \\
\hline \multicolumn{4}{|l|}{$\overline{\text { Sex }}$} \\
\hline No. of boys (\%) & $32(58.2)$ & $27(79.4)$ & $0.06^{*}$ \\
\hline No. of girls (\%) & $23(41.8)$ & $7(20.6)$ & $0.06^{*}$ \\
\hline $\begin{array}{l}\text { Age (days, } \\
\text { mean } \pm S E M, \\
\text { median) }\end{array}$ & $8.5 \pm 0.8,6.0$ & $10.1 \pm 1.5,6.0$ & $0.8 \dagger$ \\
\hline $\begin{array}{l}\text { Weight }(\mathrm{kg}, \\
\text { mean } \pm \text { SEM, } \\
\text { median })\end{array}$ & $3.3 \pm 0.1,3.2$ & $3.3 \pm 0.1,3.3$ & $0.7 \dagger$ \\
\hline $\begin{array}{l}\text { No. of previous } \\
\text { operations (\%) }\end{array}$ & $7(12.7)$ & $5(14.7)$ & $0.99^{*}$ \\
\hline
\end{tabular}

$S E M$, Standard error of the mean.

*Fisher's exact test.

$†$ Mann-Whitney test (Wilcoxon rank-sum test).

DSC was always done in the operating room under strictly sterile conditions. The edge of the sterile drape was carefully detached from the skin and mediastinal devices. Immediately after the sterile drape and gauze dressing were removed, the patch and surrounding skin were painted with povidone-iodine $10 \%$ (Betadine) solution. Sterile drapes were placed at the edge of the patch to exclude all mediastinal devices from the sterile field. The patch and Prolene suture were removed and discarded. The mediastinal contents were then cultured for aerobic and anaerobic bacteria. Any anterior mediastinal clot and fibrinous debris were carefully debrided. No attempt was made to completely divide the filmy adhesions within the pericardial space. All intracardiac pressure monitoring devices were removed from the heart and transected at the level of the fascia. Both mediastinal tubes were irrigated with saline, and one of them was shortened by transecting it near the level of the diaphragm. The mediastinum was then irrigated with an antibiotic solution.

Four 25-gauge stainless steel wires were used to reapproximate the sternum. The linea alba, presternal fascia, and subcutaneous tissue were loosely reapproximated with widely spaced, interrupted, 3-0 Vicryl suture (Ethicon, Inc.) The skin edges were sutured with widely spaced and very loosely tied 4-0 nylon. Povidone-iodine $10 \%$ ointment was liberally applied to the skin edges. An occlusive gauze and iodine-impregnated sterile drape dressing was applied. At the end of the procedure, the intracardiac devices that had been extracted from the heart and cut at the fascial level were removed by pulling their remnants through the skin.

The patients were returned to the pediatric intensive care unit where the occlusive dressings were left undisturbed until the wounds were inspected 48 hours later. A dry, sterile dressing was maintained until the skin edges were completely healed. The loose, nylon skin sutures were typically removed on the fifth day after DSC.

Antibiotic coverage. Treatment with an intravenous firstgeneration cephalosporin was maintained until the time of DSC and then replaced by an intravenous penicillinase-resistant penicillin and an aminoglycoside antibiotic. The antibiotics were changed earlier if the patient demonstrated an abnormally prolonged and elevated temperature at least 48 hours after the open heart procedure. The perioperative antibiotics were typically discontinued 48 hours after DSC provided the intraoperative cultures were negative, the patient had no clinical or laboratory signs of infection, and the wound appeared uninfected.

Analysis of hospital course. The durations of ventilatory support, inotropic support, and hospital stay were measured to the nearest hour and converted into days. Significant inotropic support was defined as the administration of greater than 6 $\mu \mathrm{g} / \mathrm{kg} / \mathrm{min}$ of dopamine or the administration of more than one inotropic agent, regardless of the dose. We frequently administer $6 \mu \mathrm{g} / \mathrm{kg} / \mathrm{min}$ or less of dopamine to optimize renal function in patients who are not truly dependent on inotropic agents. This 
Table VI. Comparison of cardiopulmonary bypass, total circulatory arrest, and global myocardial ischemia times between the PEOS and PSC groups

\begin{tabular}{|c|c|c|c|c|c|}
\hline \multirow[b]{2}{*}{ Variable } & \multicolumn{2}{|r|}{ PEOS } & \multicolumn{2}{|r|}{$P S C$} & \multirow{2}{*}{$\begin{array}{c}\mathrm{p} \text { Value for the difference } \\
\text { between means* }\end{array}$} \\
\hline & No. & $M e a n \pm S E M(\min )$ & No. & $\overline{M e a n} \pm S E M(\min )$ & \\
\hline CPB time & 55 & $151.9 \pm 10.7$ & 34 & $121.0 \pm 12.1$ & 0.07 \\
\hline TCA time $†$ & 36 & $58.5 \pm 4.0$ & 19 & $55.3 \pm 5.8$ & 0.6 \\
\hline GMI time & 55 & $98.9 \pm 4.7$ & 34 & $86.8 \pm 6.2$ & 0.1 \\
\hline
\end{tabular}

$S E M$, Standard error of the mean; $C P B$, cardiopulmonary bypass; $T C A$, total circulatory arrest; $G M I$, global myocardial ischemia.

*Student's unpaired $t$ test.

$t_{p}$ Value for difference in frequency of use of total circulatory arrest between the PEOS $(n=36,65.5 \%)$ and PSC $(n=19,55.9 \%)$ groups $=0.4$ (Fisher's exact test).

Table VII. Indications for PEOS

\begin{tabular}{lc}
\hline \multicolumn{1}{c}{ Indication } & No. (\% of 55) \\
\hline Cardiac compression (drop in SBP, & $43(78.2)$ \\
rise in LAP) & \\
Respiratory compromise & $7(12.7)$ \\
Bradycardia & $2(3.6)$ \\
Cardiac compression \& respiratory & $2(3.6)$ \\
compromise & $1(1.8)$ \\
Indication not known & \\
\hline
\end{tabular}

$S B P$, Systemic blood pressure; $L A P$, left atrial pressure.

definition of significant inotropic support more accurately reflects the period of time during which the patients required inotropic agents to maintain a satisfactory cardiac output.

Data collection and analysis. All data were sorted on the Microsoft Excel for Windows program version 4.0* and were downloaded into SPSS for Windows release 5.0 0 for statistical analysis. Quantitative variables that approximated a normal distribution were reported as the mean plus or minus the standard error of the mean and were analyzed by the Student's unpaired $t$ test. Quantitative variables that did not approximate a normal distribution were reported as the mean plus or minus the standard error of the mean with the median and were analyzed by the Mann-Whitney test (Wilcoxon rank-sum test). Nominal variables were analyzed nonparametrically by the Fisher's exact or the $\chi^{2}$ test. A $p$ value less than 0.05 was considered statistically significant.

\section{Results}

Preoperative characteristics. Of the 89 patients in the study population, 55 (61.8\%) underwent PEOS and 34 (38.2\%) underwent PSC. The analyzed preoperative characteristics (Table V) of the PEOS and PSC groups were similar; however, the difference in the sex distribution between the two groups did approach statistical significance. The distributions of the cardiac diagnoses in the two groups were different $(p=0.001)$. This was probably because of the higher frequencies of hypoplastic left heart

*Microsoft Corp., Redmond, Wash.

†SPSS Inc., Chicago, Ill.
Table VIII. Comparison of postoperative variables between the PEOS/DSC and PSC hospital survivors

\begin{tabular}{cccc}
\hline $\begin{array}{c}\text { Postoperative } \\
\text { variable }\end{array}$ & $\begin{array}{c}\text { PEOS/DSC } \\
\text { survivors } \\
(\mathrm{n}=44)^{*}\end{array}$ & $\begin{array}{c}\text { PSC } \\
\text { survivors } \\
(\mathrm{n}=29)^{*}\end{array}$ & $\begin{array}{c}\mathrm{p} \text { Value } \\
\text { for the } \\
\text { differencet }\end{array}$ \\
\hline $\begin{array}{c}\text { Mechanical } \\
\text { ventilation }\end{array}$ & $9.7 \pm 0.9,7.7$ & $9.9 \pm 3.4,4.9$ & 0.0005 \\
$\begin{array}{c}\text { Inotropic } \\
\text { support } \\
\text { Hospital } \\
\text { stay }\end{array}$ & $3.0 \pm 0.3,2.8$ & $2.7 \pm 0.4,2.1$ & 0.3 \\
\hline
\end{tabular}

*Values are length of time in days; mean plus or minus standard error of the mean, median.

†Mann-Whitney test (Wilcoxon rank-sum test).

syndrome and transposition of the great arteries with ventricular septal defect in the PEOS group and the greater frequency of miscellaneous diagnoses in the PSC group (Table III).

Technique of myocardial protection. Cold $\left(4^{\circ} \mathrm{C}\right)$ hyperkalemic, dilute sanguinous cardioplegia was used in $49(89.1 \%)$ of the patients with PEOS and in $29(85.3 \%)$ of the patients with PSC. Deep hypothermia and crystalloid cardioplegia were used early in the series in 11 (12.4\%) patients. The $p$ values for the differences between the frequencies of use of these various forms of myocardial protection were not significant between the two groups (Table IV).

Intraoperative variables. The durations of cardiopulmonary bypass, total circulatory arrest, and global myocardial ischemia were not significantly different between the PEOS and PSC groups (Table VI). The difference in the cardiopulmonary bypass times did, however, approach statistical significance; the duration in the PEOS group was $151.9 \pm 10.7$ minutes versus 121.0 \pm 12.1 minutes in the PSC group $(p=0.07)$. The frequencies of the use of total circulatory arrest in the PEOS (65.5\%) and PSC (55.9\%) groups were similar $(p=0.4)$. 
Table IX. Morbidity in the PEOS/DSC and PSC hospital survivors

\begin{tabular}{|c|c|c|c|c|c|}
\hline \multirow[b]{2}{*}{ Complication } & \multicolumn{2}{|c|}{$\begin{array}{l}\text { PEOS/DSC survivors } \\
\quad(\mathrm{n}=44)\end{array}$} & \multicolumn{2}{|c|}{ PSC survivors $(\mathrm{n}=29)$} & \multirow{2}{*}{$\begin{array}{l}\mathrm{p} \text { Value for } \\
\text { the difference* }\end{array}$} \\
\hline & No. & $\%$ of 44 & No. & $\%$ of 29 & \\
\hline Renal failure & 2 & 4.5 & 0 & 0 & \\
\hline Seizures & 3 & 6.8 & 3 & 10.3 & \\
\hline Diaphragmatic paralysis & 2 & 4.5 & 0 & 0 & \\
\hline Staphylococcus epidermidis sepsis & 2 & 4.5 & 0 & 0 & \\
\hline Superficial wound infection & 1 & 2.3 & 0 & 0 & \\
\hline Atrioventricular dissociation & 1 & 2.3 & 0 & 0 & \\
\hline $\begin{array}{l}\text { Low cardiac output necessitating } \\
\text { delayed sternal reopening }\end{array}$ & Not applicable & & 7 & 24.1 & \\
\hline $\begin{array}{l}\text { Total No. of patients with } \\
\text { complications } \dagger\end{array}$ & 8 & 18.2 & 10 & 34.5 & 0.2 \\
\hline
\end{tabular}

*Fisher's exact test.

$\uparrow$ Note that several patients had more than one postoperative complication.

Indications for PEOS. There was no discernable tendency of one surgeon of record to use PEOS/DSC more often than the other surgeon ( $p=0.6$; Fisher's exact test). The most common indication for the use of PEOS/DSC was a clinically important fall in the systemic blood pressure and rise in the left atrial pressure during the trial of sternal closure (43 patients, $78.2 \%$ ). Other indications included bradycardia, impaired ventilation and oxygenation, or a combination of any of the indications (Table VII).

Interval from PEOS to DSC. Six (10.9\%) of the neonates having PEOS died before DSC. The remaining 49 patients comprise the PEOS/DSC group. The interval to DSC in this group was $4.0 \pm 0.2$ days. Of the 34 patients in the PSC group, 7 (20.6\%) underwent delayed reopening of the sternum during the postoperative period to treat low cardiac output refractory to medical treatment. All of these patients underwent DSC at an interval of $4.2 \pm 0.4$ days and survived. These seven patients were analyzed in the PSC group because they initially had undergone PSC.

Postoperative variables. The lengths of postoperative mechanical ventilation and hospital stay were significantly longer in the PEOS/DSC survivor group than in the PSC survivor group. The duration of significant inotropic support was similar in both groups (Table VIII).

Morbidity. Postoperative seizure activity was the most common complication in both groups. Renal failure and diaphragmatic paralysis each occurred in two (4.5\%) of the PEOS/DSC survivors. The only infectious complications in this series occurred in the PEOS/DSC group. Two (4.5\%) patients had Staphylococcus epidermidis line sepsis, and one (2.3\%) patient had a superficial wound infection that responded to a brief course of local wound care. A total of eight (18.2\%) of the PEOS/DSC survivors had one or more postoperative complications com- pared with $10(34.5 \%)$ of the PSC survivors $(p=0.2)$. The major source of morbidity in the PSC survivors was the urgent need to perform delayed sternal reopening in $24.1 \%$ (20.6\% of the total PSC group).

Postoperatively, two (3.6\%) patients in the PEOS/ DSC group and two (5.9\%) patients in the PSC group were maintained on extracorporeal membrane oxygenation support ( $p=0.99$; Fisher's exact test). None of the patients in this series required reoperation for postoperative mediastinal hemorrhage (Table IX).

Mortality. In one (1.8\%) patient in the PEOS group an initial attempt of sternal closure failed 5 days after the open heart repair. This patient's chest was closed 5 days after this initial attempt; however, he eventually died of low cardiac output. There were $11(20 \%)$ total hospital deaths in the PEOS group compared with 5 (14.7\%) in the PSC group ( $p=0.6$; Fisher's exact test). Six (54.5\%) of the 11 hospital deaths in the PEOS group occurred before DSC; the five $(45.5 \%)$ remaining deaths in this group occurred after DSC.

\section{Discussion}

In 1975, Riahi and colleagues ${ }^{2}$ emphasized the importance of sternal closure as the cause of cardiac compression after cardiac operations. Jögi and Werner ${ }^{3}$ actually measured the detrimental hemodynamic effects of chest closure after complex cardiac operations for congenital disease. They hypothesized that the rise in pericardial pressure produced by sternal closure caused a fall in the transmural left and right ventricular end-diastolic pressures. The concomitant rise in left and right atrial pressures only partially compensated for this effect, and this resulted in a reduction of end-diastolic ventricular volumes. This hypothesis was supported by the work of Matsumoto and colleagues. ${ }^{5}$ Their echocardiographic 
Table X. A comparison of all pediatric series of DSC in the literature

\begin{tabular}{|c|c|c|c|c|c|}
\hline Series & $\begin{array}{c}\text { No. of } \\
\text { pediatric patients }\end{array}$ & $\begin{array}{l}\% \text { of } \\
\text { total* }\end{array}$ & Age range & $\begin{array}{l}\text { No. with wound } \\
\text { infection (\%) }\end{array}$ & Deaths (\%) \\
\hline $\operatorname{Bex}^{23}(1979)$ & 4 & Not reported & $10 \mathrm{dy}-8 \mathrm{yr}$ & $0(0)$ & $0(0)$ \\
\hline Björk $^{18}$ (1982) & 5 & Not reported & Not reported & $0(0)$ & $3(60)$ \\
\hline Shore $^{31}(1982) \dagger$ & 9 & Not reported & 6 wk- 6 yr & $0(0)$ & $2(22.2)$ \\
\hline Fanning ${ }^{13}$ (1987) & 12 & Not reported & $10 \mathrm{wk}-9 \mathrm{yr}$ & $1(8.3)$ & $2(16.7)$ \\
\hline Odim $^{4}(1989) \ddagger$ & 9 & 30 & $3 d y-31 d y$ & $0(0)$ & $2(22.2)$ \\
\hline Baumgart ${ }^{17}(1991)$ & 9 & 3 & $3 \mathrm{mo}-19 \mathrm{yr}$ & $0(0)$ & $0(0)$ \\
\hline Hakimi (1993) & 55 & 61.8 & $1 \mathrm{dy}-27 \mathrm{dy}$ & $1(2.3)$ & $11(20)$ \\
\hline
\end{tabular}

${ }^{*}$ Represents the percent undergoing DSC of the total number of pediatric patients operated on during the time period of the study.

tSeries of patients who underwent delayed sternal reopening (as opposed to PEOS).

$\varsubsetneqq$ This series is, to our knowledge, the only other neonatal series in the literature.

study of adults after open cardiac procedures suggested that the fall in cardiac output with sternal closure was due to impaired filling rather than to a change in contractility. In pertinent and related studies, Daughters and associates $^{6}$ and Hanley ${ }^{7}$ examined the effects of pericardial opening on the early postoperative cardiac function of adults having heart operations. Pericardial opening relieved diastolic filling constraints on the left ventricle and resulted in improved cardiac index and stroke work index.

Kay, Brass, and Lincoln ${ }^{8}$ used pericardial catheters to measure directly the rise in pericardial pressure after cardiac operations for congenital disease. They found that pericardial pressure climbed significantly after transventricular repair of tetralogy of Fallot or homograft repair of truncus arteriosus. There was a negligible rise in pressure in patients who underwent closed cardiac procedures or transatrial open cardiac operations. Del Nido and associates ${ }^{9}$ measured pericardial pressure in pediatric patients who underwent surgical correction of defects associated with large left-to-right shunts. Pericardial pressure rose with pulmonary hypertensive events and fell as these events responded to treatment. Laver, Strauss, and Pohost, ${ }^{10}$ using gated blood pool scanning, demonstrated that pulmonary vascular hypertension can precipitate myocardial compression by producing right ventricular dilation caused by an increase in right ventricular end-diastolic volume.

Although greater emphasis has been placed on poor ventricular filling as the predominant mechanism of low cardiac output caused by myocardial compression, other possible mechanisms include (1) a reduction in myocardial contractility $(\mathrm{dP} / \mathrm{dt})$ during isovolumic contraction ${ }^{11}$ or (2) a reduction in coronary blood flow as a result of a decrease in ventricular compliance. ${ }^{12}$

An important difference in the clinical characteristics of the two patient groups in this study was that the PEOS/DSC patients were, by definition, more critically ill than those in the PSC group. This may be because the frequencies of hypoplastic left heart syndrome and transposition of the great arteries with ventricular septal defect were higher in the PEOS/DSC group. The latter might explain why the longer cardiopulmonary bypass time of the PEOS/DSC group approached statistical significance when compared with that of the PSC group. The hemodilution and alterations in capillary permeability associated with this tendency toward longer cardiopulmonary bypass times in the patients having PEOS may have increased their myocardial, pulmonary, and mediastinal edema. Because the mortality of the more critically ill PEOS/DSC group was similar to that of the PSC group, our inference is that PEOS/DSC is effective in salvaging critically ill neonates in whom low cardiac output or respiratory embarrassment, or both, develop during a trial of sternal closure after open cardiac procedures. The fact that seven $(20.6 \%)$ of the patients having PSC underwent delayed sternal reopening for postoperative, refractory low cardiac output-and survived-further supports this inference.

The indications for the use of PEOS/DSC in neonates are similar to those recorded in the literature for adults and include (1) cardiac compression with associated low cardiac output, (2) respiratory compromise, (3) refractory arrhythmias, (4) uncontrollable mediastinal hemorrhage, and (5) the need to accommodate a transthoracic circulatory assist device., 13-16

Many techniques for PEOS/DSC have been proposed. These can be classified into three broad categories: (1) skin closure with or without sternal stenting, ${ }^{13-22}$ (2) patch closure of the incision with or without sternal stenting, 4, 13, 14, 23-28 and (3) mediastinal packing. ${ }^{14,29}$ Patch closure of the incision allows maximum expansion of the mediastinal space; this cannot be achieved consistently using a technique that involves skin closure. The addition of sternal stenting to skin closure enhances mediastinal decompression but may produce local wound complica- 
tions caused by skin tension. Undermining the skin closure reduces suture line tension but may produce cutaneous ischemia. The addition of sternal stenting to patch closure may be necessary when mediastinal crowding is unusually severe. Fundaro and associates ${ }^{30}$ proposed an alternative technique to PEOS/DSC: wide opening of the pleural spaces and partial left pericardiectomy combined with PSC. We use this technique frequently as an adjunct to PEOS/DSC, but there are no series in which it has been studied as the only treatment for neonatal, postoperative low cardiac output.

The morbidity of PEOS/DSC is low. The single superficial wound infection in our series was minor, and this low incidence of infectious complications in pediatric series is mirrored in the literature (Table X). It is not surprising that the durations of mechanical ventilation and hospital stay were longer in the PEOS/DSC group because these patients remained intubated in the intensive care unit for an average of 4 days before DSC. Our mortality rate of $20 \%$ is similar to the mortality rate of $22.2 \%$ reported by Odim, Tchervenkov, and Dobell ${ }^{4}$ in their series of nine neonatal cases. Other small, non-neonatal, pediatric series of DSC exist, and their reported mortalities are listed in Table X.

The limitations of this study relate to its retrospective design, hence the lack of fixed and specific numeric criteria for the selection of PEOS/DSC versus PSC at the end of each open heart procedure. Given the results of this report and the generally favorable experience with PEOS/DSC at other institutions, it is unlikely that a randomized, prospective trial will be forthcoming. A combination of parameters including the atrial pressures, the pulmonary artery pressure, the systemic pressure, the partial pressure of oxygen and carbon dioxide in the arterial blood, and the pulmonary compliance contribute to the decision to use PEOS/DSC. Because these decisions were made by the same two surgeons, usually in concert, during the entire study period and because there was no statistical difference between the frequencies with which the surgeons of record applied this technique, we believe that our criteria for performing PEOS/DSC have been uniform over time.

Conclusions. The data derived from this study support the inference that in a critically ill, neonatal population PEOS/DSC is an effective treatment for clinically significant, postoperative mediastinal compression. This technique should be used in neonates after open cardiac procedures when mediastinal edema produces frank low cardiac output or respiratory compromise, or both, during a trial of sternal closure. Given the low morbidity and potential benefits, a reasonable argument can be made for also using this technique in situations in which postoper- ative low cardiac output is anticipated. Alternatively, delayed sternal reopening can be effective in treating refractory, postoperative low cardiac output after it occurs: prompt intervention is essential to avert the disastrous consequences of delayed treatment.

We thank Shlomo S. Sawilowsky, PhD, and David C. Naftel, $\mathrm{PhD}$, for their statistical assistance.

\section{REFEREN CES}

1. Schaper J, Schwarz F, Kittstein H, et al. The effects of global ischemia and reperfusion on human myocardium: quantitative evaluation by electron microscopic morphometry. Ann Thorac Surg 1982;33:116-22.

2. Riahi M, Tomatis LA, Schlosser RJ, Bertolozzi E, Johnston DW. Cardiac compression due to closure of the median sternotomy in open heart surgery. Chest 1975;67: 113-4.

3. Jögi $P$, Werner $O$. Hemodynamic effects of sternum closure after open-heart surgery in infants and children. Scand $\mathbf{J}$ Thorac Cardiovasc Surg 1985;19:217-20.

4. Odim JNK, Tchervenkov CI, Dobell ARC. Delayed sternal closure: a lifesaving maneuver after early operation for complex congenital heart disease in the neonate. J THORAC CARDIOVASC SURG 1989;98:413-6.

5. Matsumoto M, Oka Y, Strom J, et al. Application of transesophageal echocardiography to continuous intraoperative monitoring of left ventricular performance. Am J Cardiol 1980;46:95-105.

6. Daughters GT, Frist WH, Alderman EL, Derby GC, Ingels NB, Miller DC. Effects of the pericardium on left ventricular diastolic filling and systolic performance early after cardiac operations. J THORAC CARDIOvaSC SURG 1992;104:1084-91.

7. Hanley FL. Invited letter concerning: the influence of paracardiac structures and conditions on cardiac performance in the postcardiotomy period. [Letter]. $\mathrm{J}$ THORAC CARDIOvasC SURG 1992;104:1167-9.

8. Kay PH, Brass T, Lincoln C. The pathophysiology of atypical tamponade in infants undergoing cardiac surgery. Eur J Cardiothorac Surg 1989;3:255-61.

9. del Nido PJ, Williams WG, Villamater J, Benson LN, Coles JG, Trusler GA. Pericardial pressure (PP) changes during pulmonary hypertensive crisis after cardiac surgery. Circulation 1989;74(Suppl I):II50.

10. Laver MB, Strauss HW, Pohost GM. Right and left ventricular geometry: adjustments during acute respiratory failure. Crit Care Med 1979;7:509-19.

11. Nakano J, McCurdy J, Darrow B. Effect of acute cardiac tamponade on cardiovascular dynamics. Cardiologia 1968; 53:242-52.

12. O'Rourke RA, Fischer DP, Escobar EE, Bishop VS, Rapaport E. Effect of acute pericardial tamponade on coronary blood flow. Am J Physiol 1967;212:540-56.

13. Fanning WJ, Vasko JS, Kilman JW. Delayed sternal clo- 
sure after cardiac surgery. Ann Thorac Surg 1987;44:16972.

14. Furnary AP, Magovern JA, Simpson KA, Magovern GJ. Prolonged open sternotomy and delayed sternal closure after cardiac operations. Ann Thorac Surg 1992;54:233-9.

15. Gielchinsky I, Parsonnet V, Krishnan B, Silidker M, Abel RM. Delayed sternal closure following open-heart operation. Ann Thorac Surg 1981;32:273-7.

16. Milgater E, Uretzky G, Shimon DV, Silberman S, Appelbaum A, Borman JB. Delayed sternal closure following cardiac operations. J Cardiovasc Surg 1986;27:328-31.

17. Baumgart D, Herbon G, Borowski A, de Vivie ER. Primary closure of median sternotomy with interposition of hydroxyapatite blocks. Eur J Cardiothorac Surg 1991; 5:383-5.

18. Björk VO, Papaconstantinou C. Delayed sternal closure following cardiac operation. Scand J Thorac Cardiovasc Surg 1982;16:275-7.

19. Culliford AT, Thomas S, Spencer FC. Fulminating noncardiogenic pulmonary edema: a newly recognized hazard during cardiac operations. J THORAC CARDIOvaSC SURG 1980;80:868-75

20. Majid AA. Plastic struts for delayed sternal closure [Letter]. Ann Thorac Surg 1990;50:1021.

21. Ott DA, Cooley DA, Norman JC, Sandiford FM. Delayed sternal closure: a useful technique to prevent tamponade or compression of the heart. Cardiovasc Dis Bull Tex Heart Inst 1978;5:15-8.

22. Mestres CA, Pomar JL, Acosta M, et al. Delayed sternal closure for life-threatening complications in cardiac operations: an update. Ann Thorac Surg 1991;51:773-6.
23. Bex JP, de Riberolles C, Lecompte Y, et al. Compression cardiaque lors de la fermeture du sternum apres correction de cardiopathies congenitales complexes. Ann Chir 1980; 34:198-200.

24. Gangahar DM, McGough EC, Synhorst D. Secondary sternal closure: a method of preventing cardiac compression. Ann Thorac Surg 1981;31:281-2.

25. Hanada S, Suzuki T, Takemura K, et al. Successful delayed closure of the median sternotomy wound experienced in an infant with total correction of total anomalous pulmonary venous return. Kyobu Geka 1981;33:517-9.

26. Josa M, Khuri SF, Braunwald NS, et al. Delayed sternal closure: an improved method of dealing with complications after cardiopulmonary bypass. J THORAC CARDIOvASC SURG 1986;91:598-603.

27. Martinez MJ, Albus RA, Barry MJ, Bowen TE. Treatment of cardiac compression after cardiopulmonary bypass. Am J Surg 1984;147:400-1.

28. Murphy DA. Delayed closure of the median sternotomy incision. Ann Thorac Surg 1985;40:76-7.

29. Johnson JA, Gundersen AE, Stickney ID, Cogbill TH. Selective approach to sternal closure after exploration for hemorrhage following coronary artery bypass. Ann Thorac Surg 1990;49:771-4.

30. Fundarò P, Santoli E, Rossi FS, Botta M, Santoli C. Partial pericardiectomy to prevent cardiac compression in open-heart surgery. Ann Thorac Surg 1986;41:581-4.

31. Shore DF, Capuani A, Lincoln C. Atypical tamponade after cardiac operation in infants and children. $J$ THORAC CARDIOVASC SuRG 1982;83:449-52. 